\title{
Evaluation of the behaviour of high density tailings deposition - CODELCO pilot plant
}

\author{
J. Engels Knight Piésold S.A., Chile
}

G.I. McPhail SLR Consulting Australia (Pty) Ltd, Australia

R. Jamett Knight Piésold S.A., Chile

C. Pavissich CODELCO-VP, Chile

\section{Abstract}

CODELCO is considering the implementation of high density tailings management at their Chuquicamata mine in northern Chile for its long term disposal plan. To achieve this, CODELCO commissioned the design, construction and operation of a 70 tonne/day pilot plant, fed by existing tailings. The testing programme was completed in May 2011 and consisted of laboratory rheological and characterisation assessments, pipe loop testing, beaching trials and analyses of deposition behaviour for solid contents ranging from 57-68\% $(w / w)$.

This paper describes the characteristics of the pilot plant, the testing programme, the beach trial analyses and the resulting beach profile predictions based on the Stream Power theory.

CODELCO also used other predictive beach slope methods, such as the Equilibrium Slope concept, which are not discussed in this paper. The final beach profile for design will be selected after an expert analysis of all methods has been completed.

\section{$1 \quad$ Introduction and objectives}

\section{1 Overview of the pilot plant}

A pilot plant for testing high density thickened tailings was commissioned in January 2011 for the Chuquicamata Project in Northern Chile, owned and operated by CODELCO. The pilot plant was designed and operated by a joint venture consisting of Knight Piésold (KP), Paterson \& Cooke (P\&C) and EIC Ingenieros (EIC). The objectives of the pilot plant were to determine the design parameters for implementing a high density thickened tailings discharge system within Tranque Talabre, the existing and active tailings storage facility.

The long term plan for tailings storage within Talabre is to minimise water losses, optimise storage capacity and life of the facility, while at the same time reducing operating costs. Due to the size of Talabre $(5,000 \mathrm{ha})$, it is feasible to reduce retaining wall heights by increasing the beach slope and in situ density and applying a high density thickened tailings discharge system.

The fundamental objectives of the pilot plant were to determine the deposition behaviour of the tailings at concentrations of $57 \%$ (as currently produced), 63,65 and $68 \%$ solids (w/w) and to assess thickener performance to achieve these concentrations. The key components of the pilot plant are summarised as follows and identified in Figure 1:

- Pilot paste thickener (2.5 m diameter, $11 \mathrm{~m}$ high): Designed and operated by Outotec, with a maximum capacity of 70 tonne/day.

- Pipe loops: Designed and operated by P\&C. Two pipe loops of 3 and 4 inch diameter $(7.6 \mathrm{~cm}$ and $10.2 \mathrm{~cm}$ ) were assembled to allow operation of three configurations $(78 \mathrm{~m}$ of $7.6 \mathrm{~cm}, 80 \mathrm{~m}$ of 
$7.6-10.2 \mathrm{~cm}, 106 \mathrm{~m}$ of $7.6-10.2 \mathrm{~cm}$ ) together with a laboratory for sample preparation and testing. Rheological testing in the laboratory was completed using a Haake VT550.

- Fixed flumes of Knight Piésold (KP): Designed and operated by Knight Piésold. 8 flumes were constructed from sand bags and lined with Linear Low Density Polyethylene (LLDPE) with geotextile on the base. Each flume was $0.75 \mathrm{~m}$ wide and $50 \mathrm{~m}$ in length, two flumes had a base gradient of $0.5 \%$ and maximum height of $1.0 \mathrm{~m}$, and six flumes had a base gradient of $1.0 \%$ and maximum height of $1.5 \mathrm{~m}$. There were four groups of two flumes each, one with underdrainage installed, the other without. A single concentration of solids was applied to each group, G1 (57\%), G2 (63\%), G3 (65\%) and G4 (68\%), as shown in Figure 1. A series of laboratory tests was also completed to determine characteristics of the tailings for the different concentrations deposited.

- Fixed flumes of Gordon McPhail: Designed by Gordon McPhail and operated by Knight Piésold. Two flumes were constructed, one small flume of $1.8 \mathrm{~m}$ wide, $8 \mathrm{~m}$ long and $0.7 \mathrm{~m}$ high and one large flume of $2.5 \mathrm{~m}$ wide, $20 \mathrm{~m}$ long and $1 \mathrm{~m}$ high. Each flume had a counter-gradient of $0.5 \%$ and was constructed of concrete. A bobcat was used to clean the flumes after testing was completed.

- Variable flume: Designed and operated by ATC Williams Pty Ltd. Two half pipe flumes were developed and placed inside a wider flume and used independently to develop a self-formed channel.

All installed distribution pumps for the thickened tailings were peristaltic style (Bredel SPXs) feeding High Density Polyethylene (HDPE) pipelines and flexible mine hoses.

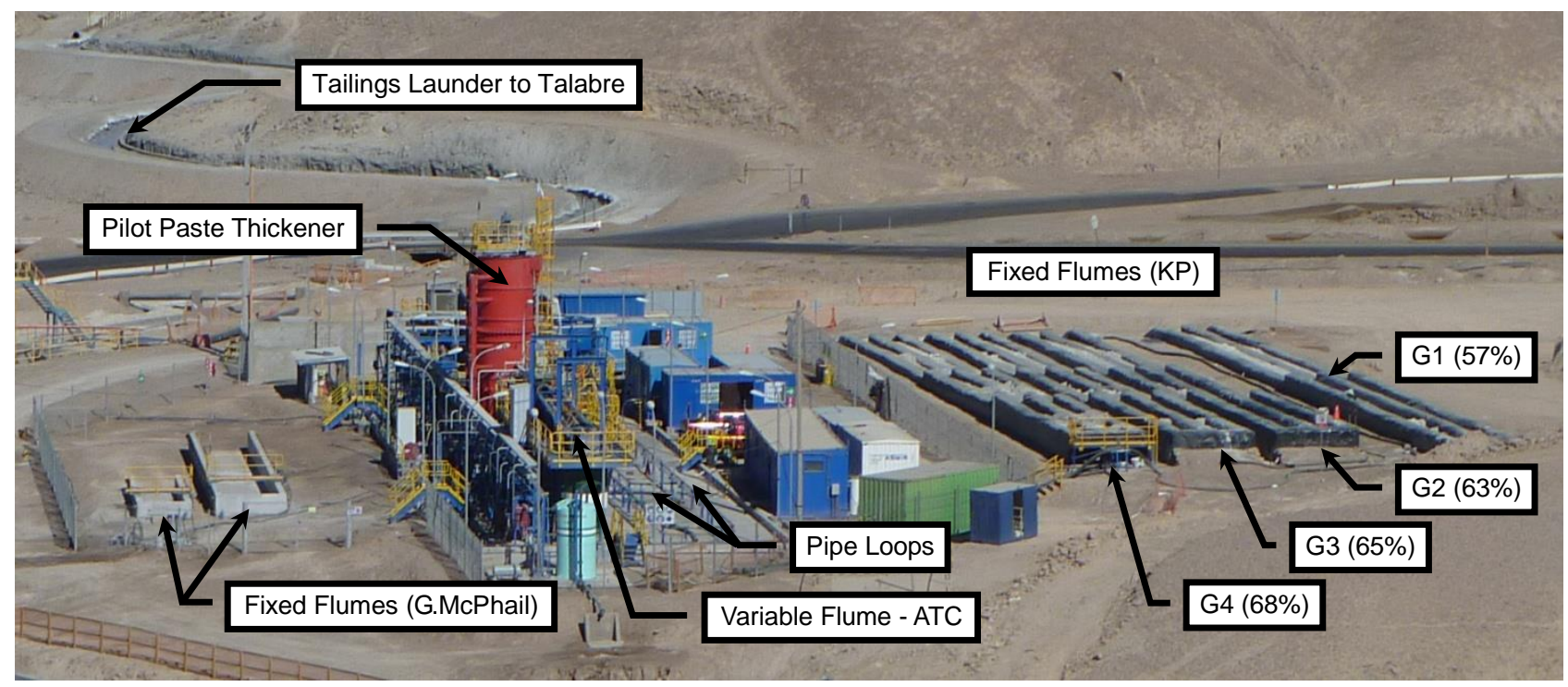

Figure 1 Pilot plant layout

Based on laboratory testing by Outotec, a maximum concentration of $71 \%$ solids was proposed, but during commissioning and operation of the pilot plant a sufficient volume of tailings at this concentration could not be achieved to feed all the flumes. As a result, $68 \%$ solids was the maximum that could be considered for testing purposes. The thickener produced paste of up to $76 \%$ solids in batches, but could not maintain consistency in discharge concentrations over $68 \%$ solids (not paste).

This paper presents the key results of the fixed flumes of Knight Piésold and Gordon McPhail, with their subsequent laboratory analyses (Engels et al., 2011; McPhail, 2011). Other predictive beach slope methods, such as the Equilibrium Slope concept (variable flume), the results from the pipe loops and details of the pilot paste thickener are not discussed in this paper. 


\subsection{Fixed flumes (KP) and KP laboratory}

The concept behind the fixed flumes (KP) was to determine changes in the deposition characteristics of tailings when discharged sub-aerially in an open channel for a range of solids concentrations. The focus of the operation of these fixed flumes was to determine the effects of drying, the potential water recovery and the changes in density. Beach slopes were also measured in the fixed flumes but the methodologies of ATC Williams and Gordon McPhail were considered more reliable for determining design beach slopes for the full scale operation. Samples were collected to determine segregation of the tailings along the flume and consolidation effects when each layer had dried.

Figure 2 shows the typical deposition methodology used for discharging tailings in the fixed flumes. Both flumes of one group were filled immediately after one another, discharging at an average rate of $5 \mathrm{l} / \mathrm{s}$ with a total deposited volume of between 7 and $10 \mathrm{~m}^{3}$ in each flume per layer. A Marcy balance and oven drying techniques were used to confirm the solids concentrations of all layers discharged in each flume.
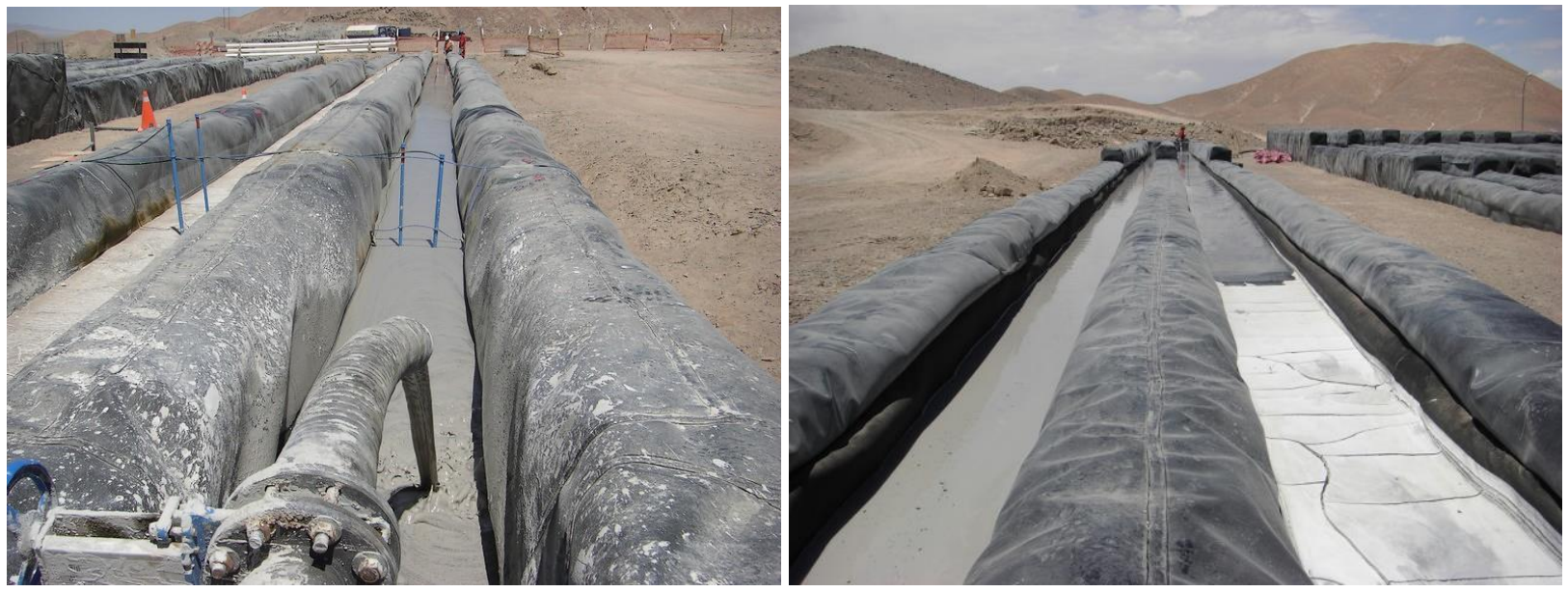

Figure 2 Fixed flumes (KP) - discharge methodology (looking downstream and upstream)

Tailings were allowed to discharge past the end of the flumes, to ensure adequate layer depth formation and achieve the equilibrium beach slope and a more uniform layer thickness. A concrete collection channel was installed at the downstream end of the flumes to return overflow tailings to the main tailings discharge launder leading to Tranque Talabre.

As an addition to the field trial experiments, laboratory testing was carried out to verify the results obtained in the fixed flumes and to determine additional tailings parameters important for the purposes of final design. These included the following:

- classification tests

- undrained and drained sedimentation tests

- air drying tests

- permeability tests

- consolidation tests

- rheological behaviour.

Classification testing was performed to confirm that the properties of the tailings were similar for all laboratory samples and for each layer deposited in both the fixed flumes (KP) and the flumes of Gordon McPhail. The tailings characteristics varied slightly during operation of the pilot plant having a $P_{80}$ of 210-350 $\mu \mathrm{m}$ and a $P_{50}$ of $60-150 \mu \mathrm{m}$. The material was non-plastic with a USCS classification varying from SM to ML. 
Based on the topics discussed in this paper relating to the fixed flumes (KP), only laboratory results relative to drying and density are presented, which consists of data from the sedimentation tests and air dry tests. Rheology results are discussed as part of the investigations of beach slope prediction based on the stream power approach.

\section{3 Fixed flumes of Gordon McPhail}

Discharge rates into the two flumes of Gordon McPhail were regulated to $8.5 \mathrm{l} / \mathrm{s}$ in the larger flume and $2 \mathrm{l} / \mathrm{s}$ in the smaller flume. The purpose of constructing and using two flume sizes was to be able to assess the influence of discharge rate and flume geometry on the results derived from the beaching tests. Figure 3 shows the larger flume undergoing survey measurement following deposition. The smaller flume is visible on the right of the picture.

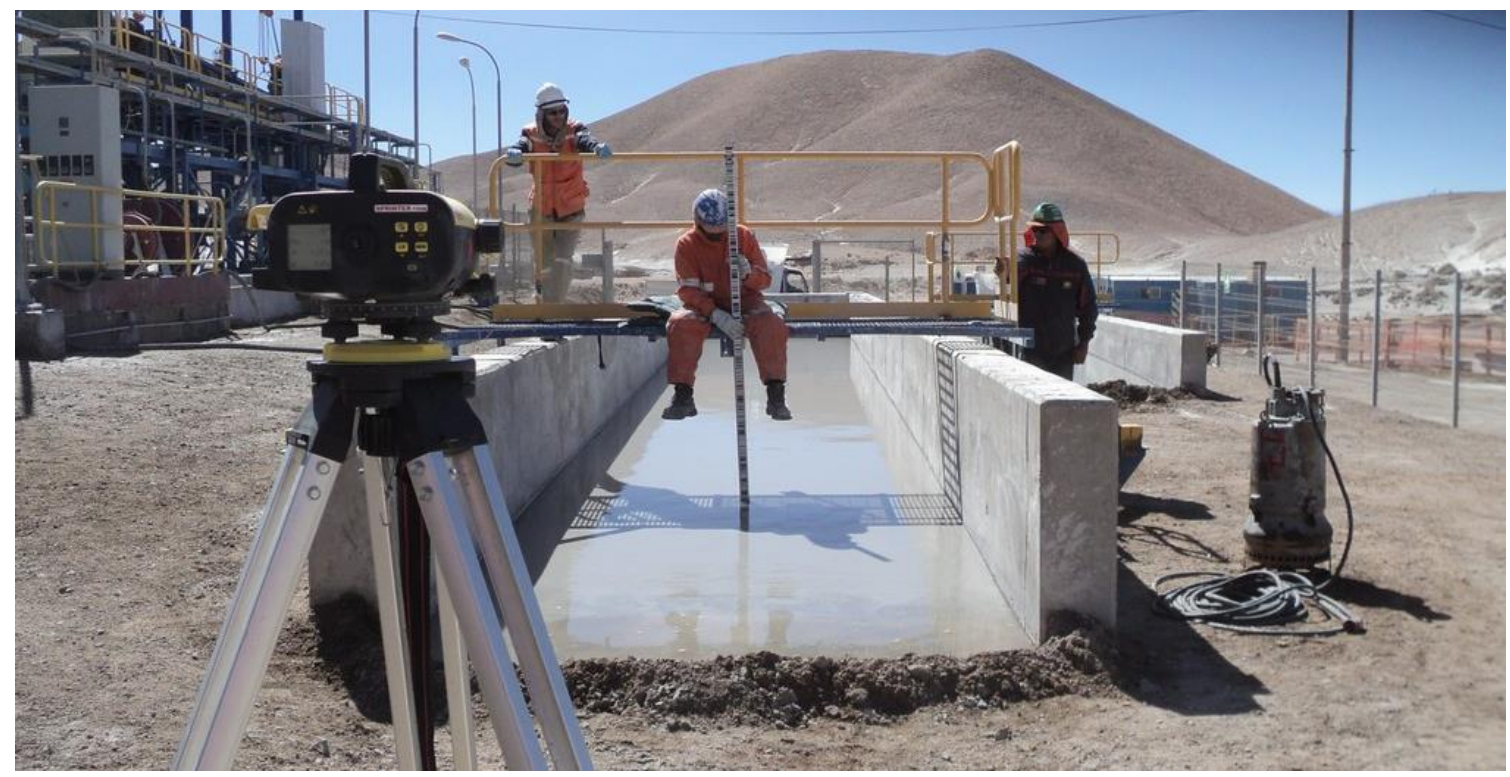

Figure 3 Measurements within the larger flume

The discharge arrangement used at the head of each flume is shown in Figure 4. Slurry is pumped from the thickened tailings feed tank to a small header tank, which ensures that the discharge head remains as steady as practicable. Measurements of the discharge and the resulting plunge pool are taken during active deposition, as indicated in Figure 4 ( $A$ to $D$ ).

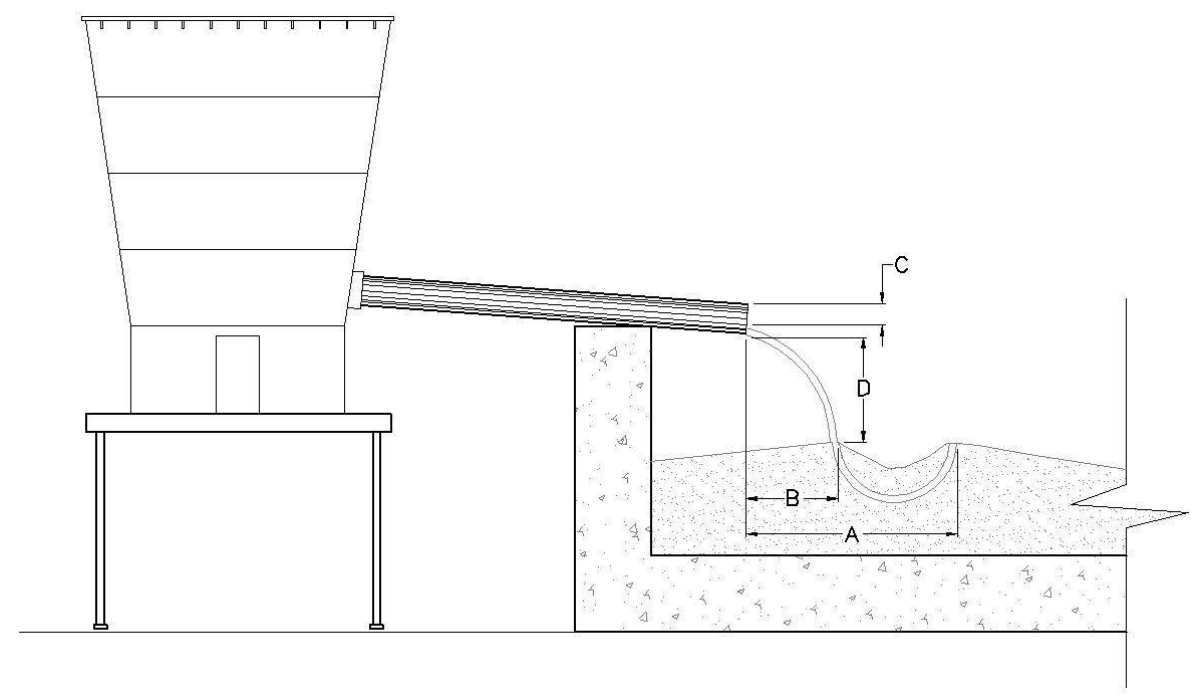

Figure 4 Discharge arrangement and measurement in both flumes 
Samples of slurry are taken during the course of the trial and used to determine the slurry density, rheological properties using vane and Couette viscometers, and particle size distribution. Once the tailings have advanced to within $1.5 \mathrm{~m}$ of the end of the flume, the rate of advance of the tailings front is measured and the dimensions of the front and the elevation of the tailings at the discharge are taken. Deposition is terminated when the tailings front is within $0.5 \mathrm{~m}$ of the end of the flume.

As soon as deposition is stopped and the header tank disassembled, the surface of the tailings along the centreline of the flume is surveyed so as to obtain a longitudinal profile of the deposited tailings.

The measured data is processed by:

- Calculating the plunge pool forces and velocities.

- Fitting a stream power-entropy beach equation to the measured beach profile by varying the slurry friction factor.

- Calculating the shear rate and shear stress at the lip of the plunge pool. This represents the shear rate and shear stress characteristic of the source slurry.

\section{1 Introduction}

Sufficient time for drying in order to achieve density and strength gain is an important design consideration, primarily to optimise the storage capacity within a tailings facility and improve stability during seismic events. To measure this parameter, a series of instruments were employed to evaluate the surface and subsurface movements of water within the tailings mass during subsequent layer deposition. These are described as follows:

- Electronic tensiometers and piezometers: Placed in the first deposited layer in each flume at a distance of 5 and $25 \mathrm{~m}$ from the point of discharge. Used to record positive (piezometers) and negative (tensiometers) pore pressures within the tailings mass. The piezometers incorporated special low pressure sensors to suit the anticipated depth of tailings within each flume.

- Lysimeters: A cost effective device used to measure evaporation from the surface of the tailings. A single open ended PVC tube filled with tailings is placed in a larger diameter PVC tube which is sunk into the tailings beach.

- Underdrainage flow meters: Used to measure the volume of underdrainage collected during and after discharge of each layer in the flumes where a drainage layer was installed. A small sump at the end of the flume connected to a $2 \mathrm{~cm}$ domestic flow meter was used to record volumetric flow.

An evaporation pan (Class A) was installed next to the fixed flumes to record daily evaporation.

\section{2 Pore pressure variations}

The tensiometers and piezometers were connected to electronic logging devices that recorded pressure and temperature readings within the first layer of tailings every 10 minutes for the duration of all testing in the fixed flumes. The results indicated that for higher tailings solids concentrations, lower negative pore pressures were measured, indicating that the release of water is slower within the tailings mass. Figures $5 a$ and $5 b$ show the negative pressure readings recorded for G1 (57\%) and G4 (68\%) plotted using the same scale axes for comparison purposes. 


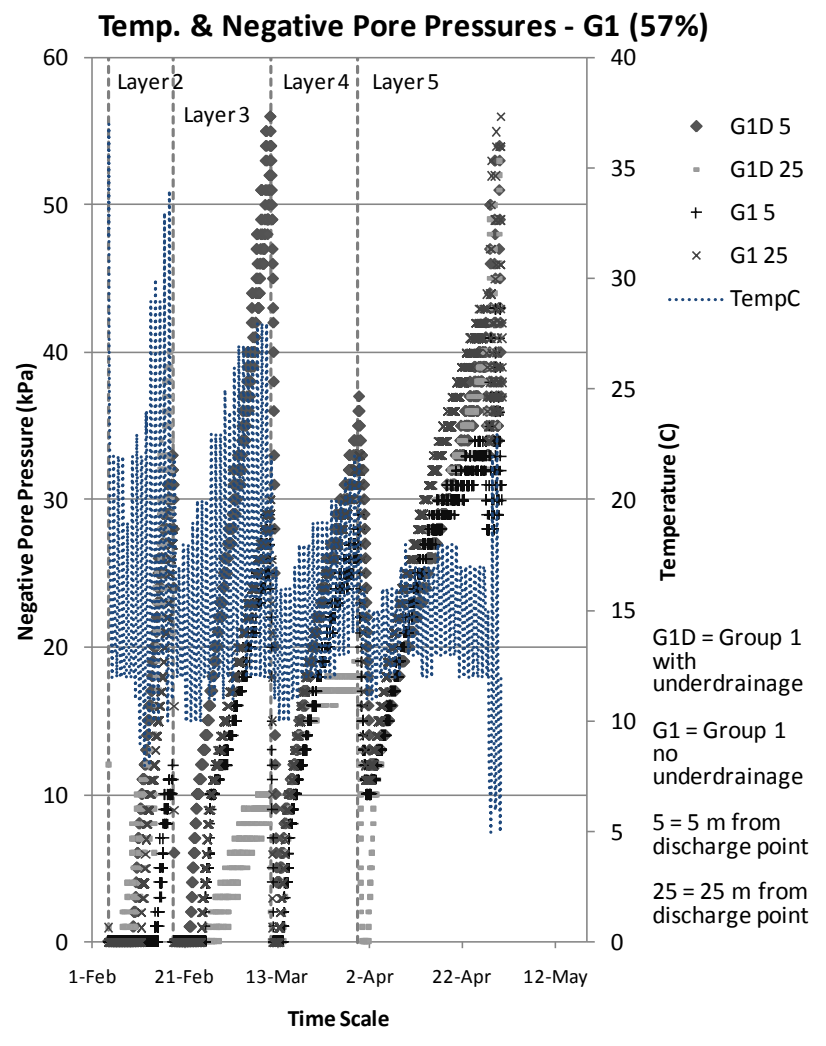

(a)

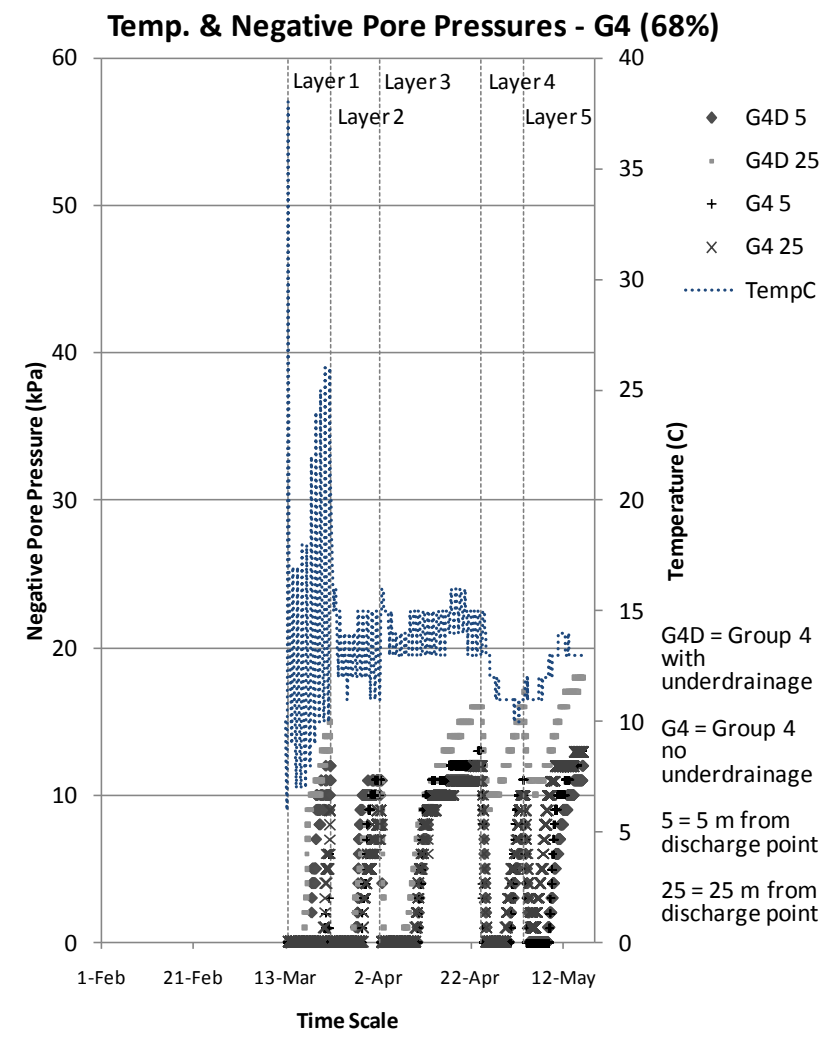

(b)

Figure 5 Temperature and negative pore pressures

The tailings are, by definition, saturated when there is zero (or positive) pressure and negative readings commence when pore water suctions develop. If these suctions exceed the air entry value of the tailings, air will enter the voids and desaturation will occur. During discharge of each subsequent layer the tailings in the first layer (where the instrumentation is installed) are resaturated and therefore zero pressure is observed. However, with each subsequent layer, the duration of saturation reduces to the extent that after deposition of the topmost layers $100 \%$ saturation in the lowermost layer does not occur, indicating the wetting front does not penetrate to the drainage/base of the flumes.

Generally with increased solids concentration, a higher moisture content is maintained over time as the tailings take longer to release water (as noted by the gradual upsloping of the $68 \%$ solids negative pressure curves in Figure $5 \mathrm{~b}$ ). This indicates that the vertical movement of water within the mass of tailings (towards the surface of the layer through capillarity or migration to layers below) is reduced. The daily temperature variations as measured at depth are also much more stable for higher solids concentrations, possibly as a consequence of differences in degrees of saturation of the tailings as retained water stabilises the daily temperature variations.

\section{3 Surface tailings evaporation and prolonged moisture content}

The results from the lysimeters show that, as the tailings solids concentration increases, the evaporative losses from the tailings surface are initially lower and prolonged as water release is slower in comparison to lower concentrations. This is evident from the changes observed in pore pressures presented previously and the results of the in situ density tests. Figure 6 a presents the averages of the lysimeter data collected for all concentrations.

On completion of all deposition trials in the flumes, a series of excavations were made along each flume to determine densities and moisture contents at depth. The moisture contents were compared to data collected from the same layers after deposition and following drying to understand how the tailings were 
retaining moisture after future layers were deposited. Due to the prolonged drying time between measurements, the results at depth are a good approximation of prolonged moisture contents for the various concentrations for the full scale operation. Figure $6 \mathrm{~b}$ is a comparison of approximate prolonged moisture contents at depth over time between $\mathrm{G} 1$ and $\mathrm{G} 4$.

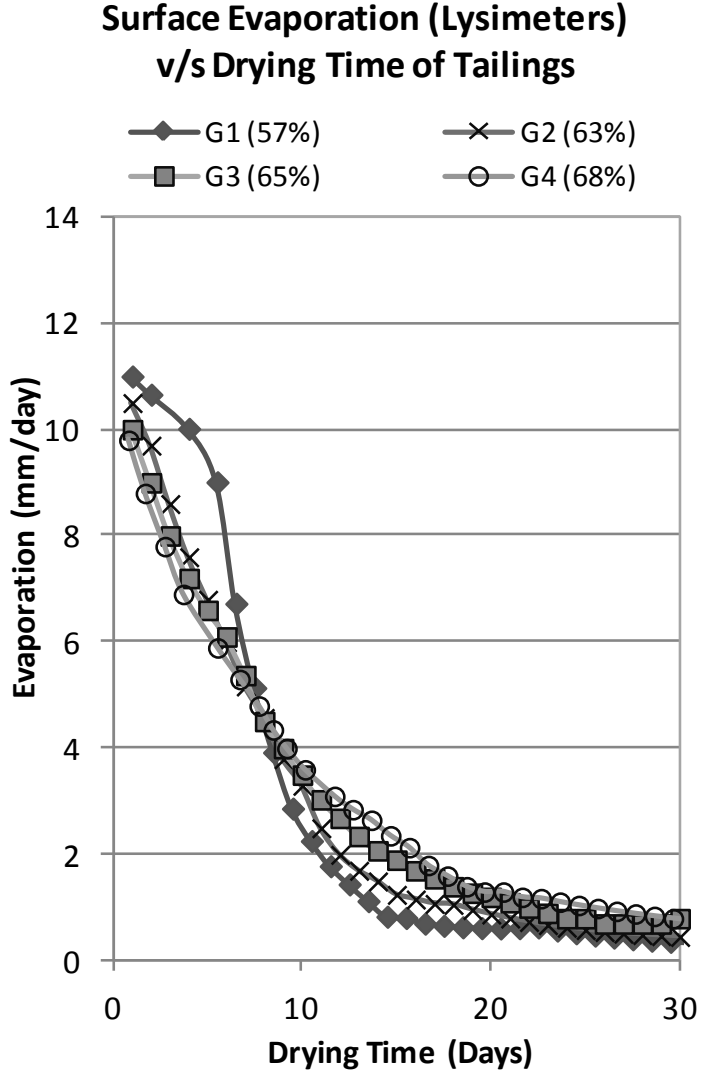

(a)

\section{Moisture Content at Depth with Time G1(57\%) \& G4 (68\%)}

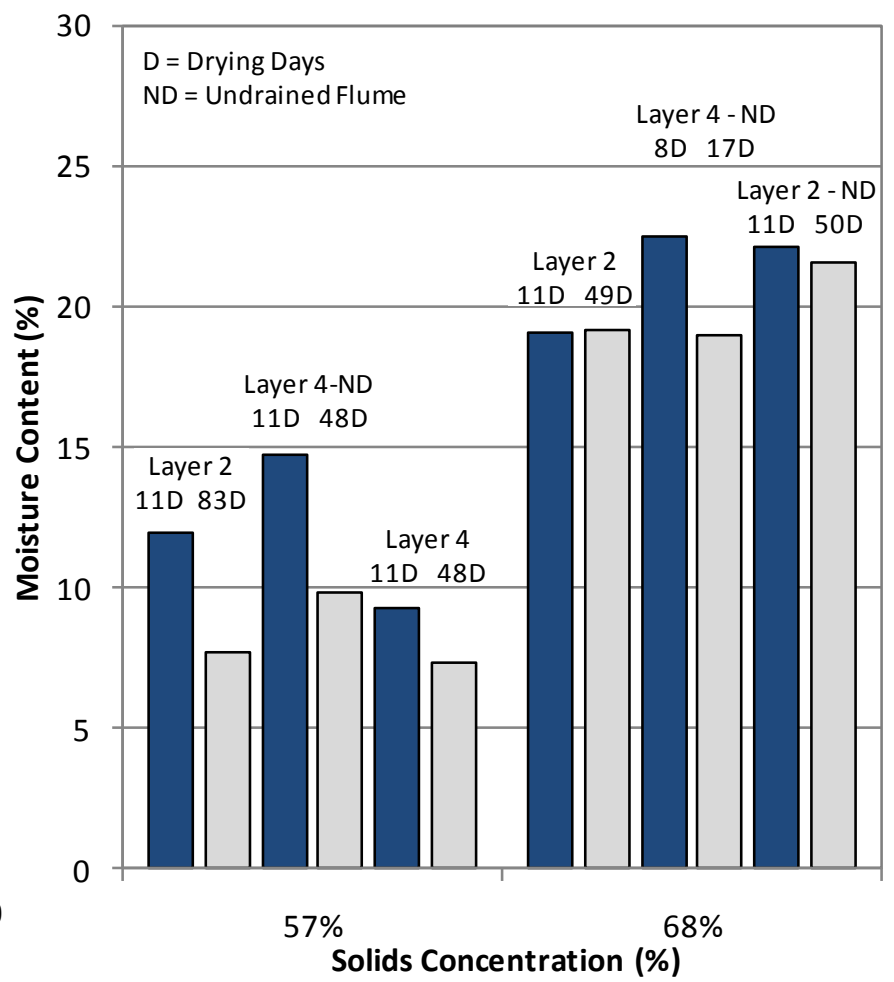

(b)

Figure 6 Summary of fixed flume (KP) Iysimeter data and prolonged moisture contents

For higher solids concentrations, the approximate prolonged moisture contents were observed to be higher, with little variation over extended periods when compared to lower solids concentrations. Table 1 is a summary of the approximate prolonged moisture contents for all concentrations, together with the corresponding degrees of saturation, as determined in the laboratory.

Table 1 Prolonged moisture content and degree of saturation

\begin{tabular}{ccc}
\hline $\begin{array}{c}\text { Group and Solids } \\
\text { Concentration (\%) }\end{array}$ & $\begin{array}{c}\text { Approx. Prolonged } \\
\text { Moisture Contents (\%) }\end{array}$ & $\begin{array}{c}\text { Approx. Degree } \\
\text { of Saturation (\%) }\end{array}$ \\
\hline G1 (57\%) & $7.5-10$ & 30 \\
G2 (63\%) & $12-14$ & 55 \\
G3 (65\%) & $12-15$ & 65 \\
G4 (68\%) & $16-22$ & 95 \\
\hline
\end{tabular}

\section{4 Liberation of water}

Estimations of the potential recovery of supernatant were determined in the laboratory for both drained and undrained conditions. A final estimation of the different percentages of recovery with data from the laboratory and the fixed flumes is presented in Figure 7. This data presumes an approximate layer thickness 
of $300 \mathrm{~mm}$ as determined in the laboratory. The lysimeter data has been used to separate losses due to evaporation from the surface of the tailings.

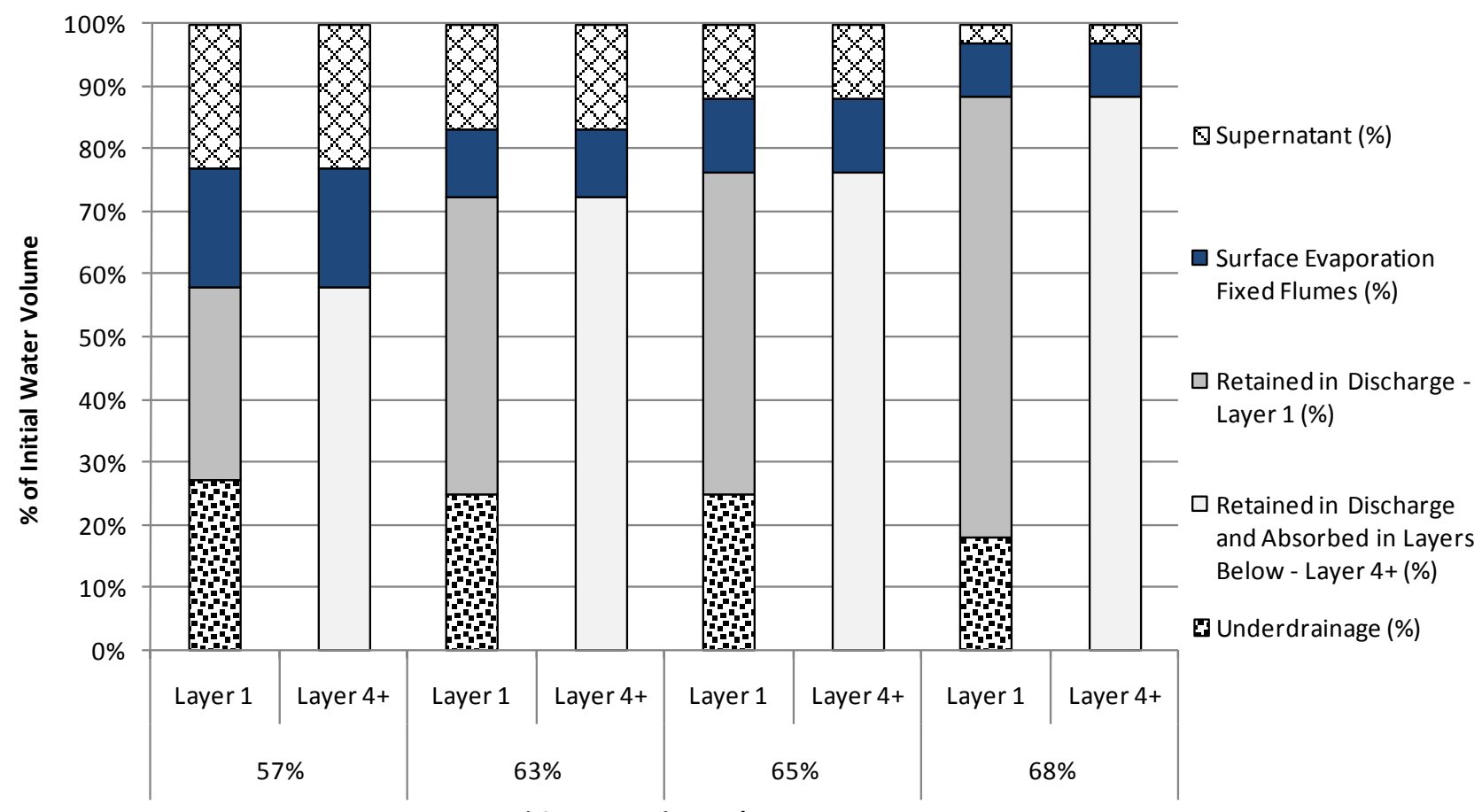

$\%$ Concentration and Layer

Figure 7 Potential water recovery and loss

The results from the fixed flumes with installed underdrainage flow meters were consistent with laboratory data for G2 and G3, where recovered underdrainage water ran clear. However, results from G1 and G4 were elevated due to small tears in the geotexile allowing supernatant water and slimes to enter the drainage system (evidenced by dirty water). Underdrainage in all flumes was recovered only in the first and second deposited layers. In subsequent discharges, infiltration water was absorbed in the previous layers after drying. From these observations, the water collected in the underdrainage and the water absorbed by underlying layers in Layer 4+ has been combined in Figure 7, based on the observations of zero underdrainage measurements and the reduced degrees of saturation as measured by the pore pressure data.

\section{$3 \quad$ In situ density and drying time derived from fixed flumes (KP)}

\section{1 Density}

Initial and final in situ density varies depending on the solids concentration of the tailings deposited within a storage facility. Different ranges of densities were measured in each group of the fixed flumes (KP) and compared with laboratory testing (air dry) using samples of the same deposited tailings. The drained and undrained sedimentation tests were used to determine the as-placed densities (saturated density) before consolidation and drying effects occurred (initial density). The optimum dry densities for each solids concentration were then obtained to determine potential final (maximum) in situ dry densities (the point when there are no further changes in volume with time). The changes in densities between the as-placed to optimum for each solids concentration were measured every two to three days after discharge of each layer deposited in the fixed flumes, using in situ density techniques.

Table 2 shows the as-placed dry densities for each concentration considered. The drained test is specific to sub-aerial deposition of tailings, which is relevant to Talabre and the tests in the fixed flumes. During this test the free surface water is continuously recovered to simulate supernatant runoff, whilst drainage water collected via the base to simulate absorption to underlying tailings or flow to installed drainage. The 
undrained sedimentation tests indicate typical densities of sub-aqueous deposition or densities in areas of ponded water.

Table 2 Final as-placed dry densities of the undrained and drained sedimentation tests

\begin{tabular}{ccccc}
\hline $\begin{array}{c}\text { Solids } \\
\begin{array}{c}\text { Concentration } \\
\text { (\%) }\end{array}\end{array}$ & $\begin{array}{c}\text { Undrained } \\
\text { Sedimentation } \\
\text { Test }\left(\mathbf{t} / \mathbf{m}^{3}\right)\end{array}$ & $\begin{array}{c}\text { Drained } \\
\text { Sedimentation } \\
\text { Test }\left(\mathbf{t} / \mathbf{m}^{3} \text { ) }\right.\end{array}$ & $\begin{array}{c}\text { Increase in Density } \\
\text { with Drainage/ } \\
\text { Absorption (\%) }\end{array}$ & $\begin{array}{c}\text { Solids } \\
\text { Concentration } \\
\text { Final } \\
\text { (Drained) (\%) }\end{array}$ \\
\hline $57 \%$ & 1.13 & 1.38 & 22 & $73 \%$ \\
$63 \%$ & 1.24 & 1.47 & 19 & $75 \%$ \\
$65 \%$ & 1.28 & 1.53 & 20 & $78 \%$ \\
$68 \%$ & 1.34 & 1.51 & 13 & $77 \%$ \\
\hline
\end{tabular}

Table 3 summarises the optimum dry densities obtained in the laboratory and the in situ dry densities achieved in the fixed flumes after drying and before discharge of subsequent layers. From the excavations through the tailings, as mentioned earlier, the densities of the initial layers discharged were measured and are presented to show how changes are occurring within the mass of tailings due to prolonged consolidation effects. In situ densities were also measured within various dry zones of the Talabre deposit (originally discharged at $57 \%$ solids), away from single flow channels, which confirm the results obtained from $\mathrm{G} 1$ for the same concentration.

Table 3 Comparison of dry densities

\begin{tabular}{|c|c|c|c|c|c|c|c|c|}
\hline \multirow{2}{*}{$\begin{array}{c}\text { Solids } \\
\text { Concentration } \\
\text { (\%) }\end{array}$} & \multicolumn{2}{|c|}{ Laboratory (Air Dry) } & \multicolumn{2}{|c|}{$\begin{array}{l}\text { In Situ Dry Density } \\
\text { (Surface) }\end{array}$} & \multicolumn{3}{|c|}{ In Situ Dry Density (with Depth) } & \multirow{2}{*}{$\begin{array}{c}\text { Tranque } \\
\text { Talabre }^{2} \\
\left(\mathrm{t} / \mathrm{m}^{3}\right)\end{array}$} \\
\hline & $\underset{\left(t / m^{3}\right)}{\operatorname{Max}}$ & $\begin{array}{l}\text { Possible } \\
\text { Optimum } \\
\text { Range } \\
\text { Achievable } \\
\left(\mathrm{t} / \mathrm{m}^{3}\right)\end{array}$ & $\begin{array}{c}\text { Average } \\
\text { Dry } \\
\text { Density } \\
\left(\mathrm{t} / \mathrm{m}^{3}\right)\end{array}$ & $\begin{array}{l}\text { Optimum } \\
\text { Range }\end{array}$ & $\begin{array}{c}\text { Days Since } \\
\text { Deposition } \\
\text { (days) }\end{array}$ & $\begin{array}{c}\text { Average } \\
\text { Dry } \\
\text { Density } \\
\left(\mathrm{t} / \mathrm{m}^{3}\right)\end{array}$ & $\begin{array}{l}\text { Optimum } \\
\text { Range }\end{array}$ & \\
\hline $57 \%$ & 1.61 & $1.50-1.57$ & 1.50 & $\checkmark$ & 48 & 1.43 & $x$ & 1.50 \\
\hline $63 \%$ & 1.68 & $1.57-1.64$ & 1.63 & $\checkmark$ & 45 & 1.64 & $\checkmark$ & $N / A$ \\
\hline $65 \%$ & 1.73 & $1.62-1.69$ & $1.58^{*}$ & $x$ & 37 & 1.62 & $\checkmark$ & $N / A$ \\
\hline $68 \%$ & 1.72 & $1.61-1.68$ & $1.55^{*}$ & $x$ & 49 & 1.63 & $\checkmark$ & $\mathrm{N} / \mathrm{A}$ \\
\hline
\end{tabular}

${ }^{194}$ to $98 \%$ of maximum laboratory values (based on KP's experience of projects now in operation); ${ }^{2}$ Average of densities measured within Talabre during beach profile surveys (April to May 2011). CODELCO officially consider the average density to be $1.42 \mathrm{t} / \mathrm{m}^{3} ;{ }^{*} \mathrm{Not}$ optimum due to insufficient drying time (average of the last three layers discharged).

An important note is that the optimum dry densities for G3 (65\%) and G4 (68\%) of the fixed flumes were not achievable due to insufficient drying time before discharge of the next layer (time restraints of operation). However, estimates for the drying times needed can be projected based on initial drying behaviour, laboratory results and observed density changes. Optimum densities were obtained in G1 (57\%) and $\mathrm{G} 2(63 \%)$ of the fixed flumes.

\section{2 Drying time}

As shown by the pore pressure variations and lysimeter data, the higher the solids concentration, the slower the release of water from the tailings mass. Therefore, it is important to determine drying times for each concentration to ensure optimum (or near optimum) dry densities can be achieved before successive layers are deposited within a tailings storage facility. 
Based on the results of the fixed flumes and laboratory drying tests, the following time frames were observed to reach optimum dry densities for the various solids concentrations tested (ranges for $100 \mathrm{~mm}$ to $200 \mathrm{~mm}$ layer deposition).

Table 4 Drying times to reach optimum dry densities

\begin{tabular}{cccc}
\hline $\begin{array}{c}\text { Solids } \\
\text { Concentration } \\
\text { (\%) }\end{array}$ & $\begin{array}{c}\text { Approx. Moisture } \\
\text { Content for } \\
\text { Optimum Density } \\
\text { (\%) }\end{array}$ & $\begin{array}{c}\text { Approx. Days of } \\
\text { Drying } \\
\text { (Optimum) (\%) }\end{array}$ & $\begin{array}{c}\text { Approx. Moisture } \\
\text { Content for Near } \\
\text { Optimum Density }\end{array}$ \\
\hline $57 \%$ & 9 & $10-20$ & 17 \\
\hline $63 \%$ & 8 & $20-25$ & 15 \\
$65 \%$ & 7 & $25-35$ & 12 \\
$68 \%$ & 6 & $35-50$ & 10 \\
\hline
\end{tabular}

${ }^{1}$ The point where no further change in volume occurs taken from laboratory air-dry tests; ${ }^{2}$ The point of reduction in rapid density gain (95-98\% of optimum).

It can be seen from Table 4 that the drying times for 57 to $68 \%$ solids increase notably, even when the differences in layer thickness are taken into account. This will influence the filling plan of the tailings facility to allow inactive zones sufficient time to dry and increase towards optimum in situ dry density. The near optimum dry density values are presented for comparison (approximate point of reduction in rapid density gain), taking approximately 5 to 15 days less time (57 to $68 \%$ solids respectively) than required to achieve optimum density.

\section{$4 \quad$ Rheological properties derived from beach trial analyses}

Shear stress and shear rate figures developed from stream power-entropy based analyses of the Gordon McPhail fixed flume tests and the interpolated rheology are presented in Table 5 and plotted in Figure 8, together with flow diagrams derived from Couette viscometer testing.

Table 5 Summary of shear stress and shear rate results from the McPhail flume tests

\begin{tabular}{lcccccc}
\hline Small flume & \multicolumn{7}{l}{ ( } & & & & \\
\hline \% solids & $57.1 \%$ & $64.2 \%$ & $65.0 \%$ & $65.2 \%$ & $67.2 \%$ & $67.6 \%$ \\
Shear stress $(\mathrm{Pa})$ & 1.06 & 4.29 & 5.03 & 2.61 & 10.04 & 7.54 \\
Shear rate $\left(\mathrm{s}^{-1}\right)$ & 10.61 & 15.22 & 13.81 & 31.03 & 11.37 & 17.64 \\
\hline Large flume & & & & & & \\
\hline$\%$ solids & $57.1 \%$ & $64.2 \%$ & $65.0 \%$ & N/A & $67.2 \%$ & $68.0 \%$ \\
Shear stress $(\mathrm{Pa})$ & 6.6 & 10.81 & 14.89 & N/A & 19.04 & 14.23 \\
Shear rate $\left(\mathrm{s}^{-1}\right)$ & 1.65 & 2.38 & 2.81 & N/A & 2.05 & 3.68 \\
\hline
\end{tabular}




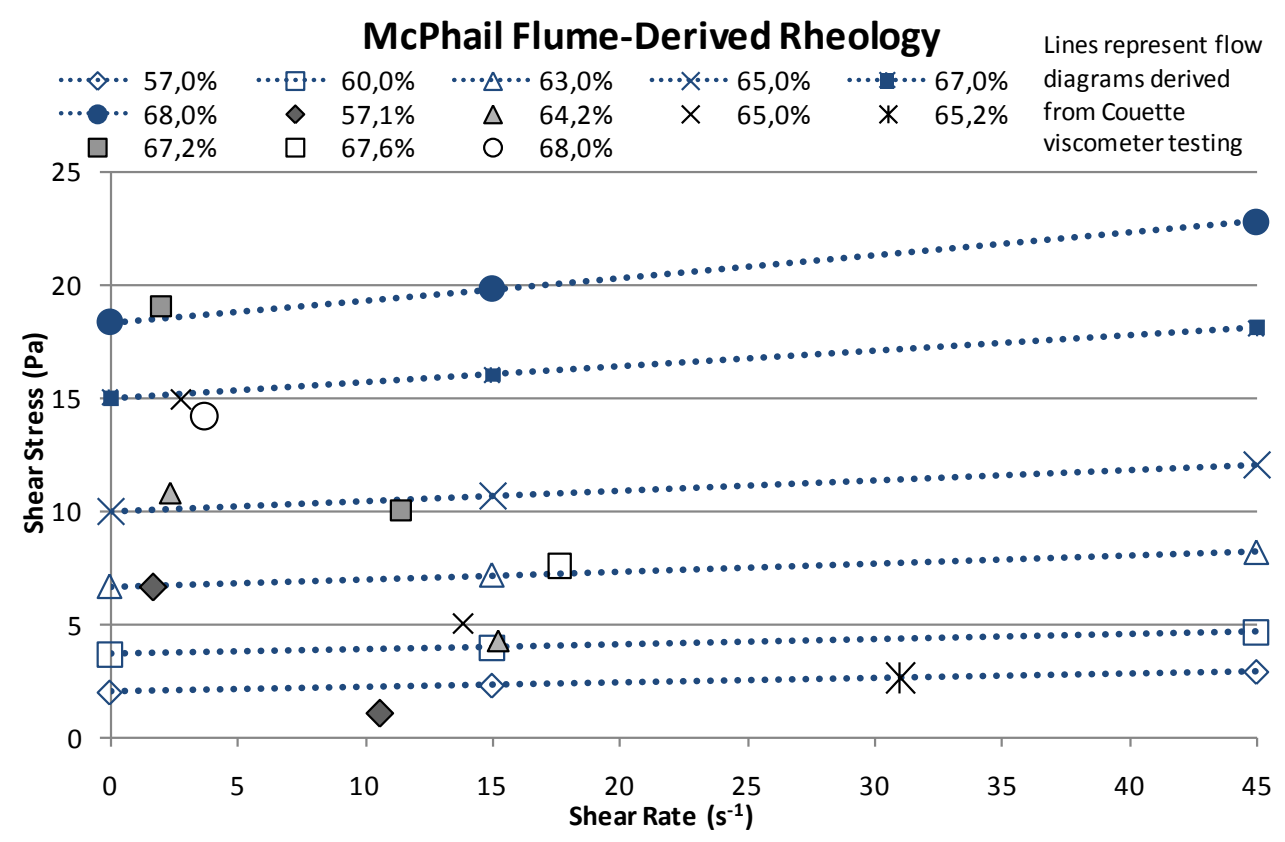

Figure 8 Flume-derived rheological results and interpolated laboratory rheology

The following points are noteworthy with respect to Figure 8:

- The shear rates from the larger flume are less than $5 \mathrm{~s}^{-1}$, while those in the smaller flume are greater than $5 \mathrm{~s}^{-1}$.

- The smaller flume significantly under-predicts the shear stress when compared with the Couette viscometer results.

In interpreting Figure 8 it is important to take into account a number of points:

- The Couette viscometer results are representative of a suspension (where settling out of solids is minimal) and not a settling slurry. At high shear rates, such as experienced in slurry pipes, this issue is of minimal concern.

- The majority of hard rock mine tailings are settling slurries with the degree of settling dependent on the particle size distribution, the slurry density and a range of other factors - not all of which are well understood. The Chuquicamata tailings fall within this class of slurries.

- While transporting the tailings in a pipeline, the design intent is to maintain velocities, and therefore shear rates, high enough to prevent settling out of the solids in the pipe. Even then it is recognised that there is stratification of the tailings in the pipe with the bed flow at a higher slurry density than the flow near the top of the pipe. This stratification is carried through to the flow stream that sets off down the beach from the plunge pool at the discharge. In this case the degree of stratification will be increased as the shear rates are lower, the slurry having lost most of its energy in the plunge pool. As a result of this increase in stratification, the rheology of the slurry at the bed of the flow channel from the plunge pool will be different from the rheology of the slurry when at shear rates high enough to maintain the solids in suspension.

- As the slurry flows beyond the plunge pool down the beach, settling takes place, with the degree of settling dependent on the energy and flow rate of the slurry. If channel flow dominates, the flow will be turbulent and the shear rates and flow rates will remain relatively constant down the stream and, consequently, the slurry remains relatively consistent. However, if sheet flow dominates, flow will be more likely to be laminar and the solids will settle rapidly. As the solids settle the percentage solids in the flowing slurry will reduce and the rheology of the slurry will change accordingly. 
- There are, therefore, two factors that influence the rheology of the slurry as it flows down the beach - the degree of stratification, which determines the rheology of the slurry just above the bed, and the residual percentage solids in the flow stream.

Full scale beach profile predictions have been calculated for each of the crests using the interpolated shear stress and shear rate results, as well as the following percent solids and spigot numbers:

- Discharge concentrations of 63,65 and $68 \%$ solids.

- Discharge rates of 30,50 and $80 \mathrm{l} / \mathrm{s}$.

Flow rates in the full scale operation will be controlled by regulating the number of spigots through which the slurry will be discharged onto the beach. It has been assumed in the analyses documented below that the flows from the spigots do not combine down the beach.

Calculation of the beach profile entails the following iterative process:

- A location on the original ground level is selected as a potential end point for the beach. This gives an elevation for the end of the beach as well as a beach length.

- The beach profile is then simulated using the stream power entropy method and the shear rate and shear stress are calculated at points down the beach. The shear stresses are termed 'predicted' shear stresses for each shear rate.

- The shear rate at each point down the beach is applied to the rheological test data to determine the characteristic shear stress for the slurry at that shear rate. This shear stress is termed the 'sustainable' shear stress.

- The 'predicted' shear stresses are compared with the 'sustainable' shear stresses and, if these differ, a new point on the beach is selected.

- This iterative process continues until the predicted and the 'sustainable' shear stresses coincide down the beach. The prediction is then considered to be equilibrated. At that stage, the most probable beach profile has been determined.

\section{$5 \quad$ Rheological properties derived from pipe loop testing}

Pipe loop testing results, analysed by $P \& C$, yielded estimates of the rheological properties of the future tailings. Upper and lower rheological boundaries were derived for various blends of ore that are likely to be discharged in Talabre in the future (from Codelco's Ministro Hales and Radomiro Tomic mines). These results show significantly higher yield stresses and stress-shear rate behaviour compared with the current tailings, as determined from laboratory and beach trial testing. Figure 9 shows plots of the yield stress versus \%solids and the Bingham viscosity versus \%solids for rheology data from the pipe loop testing.
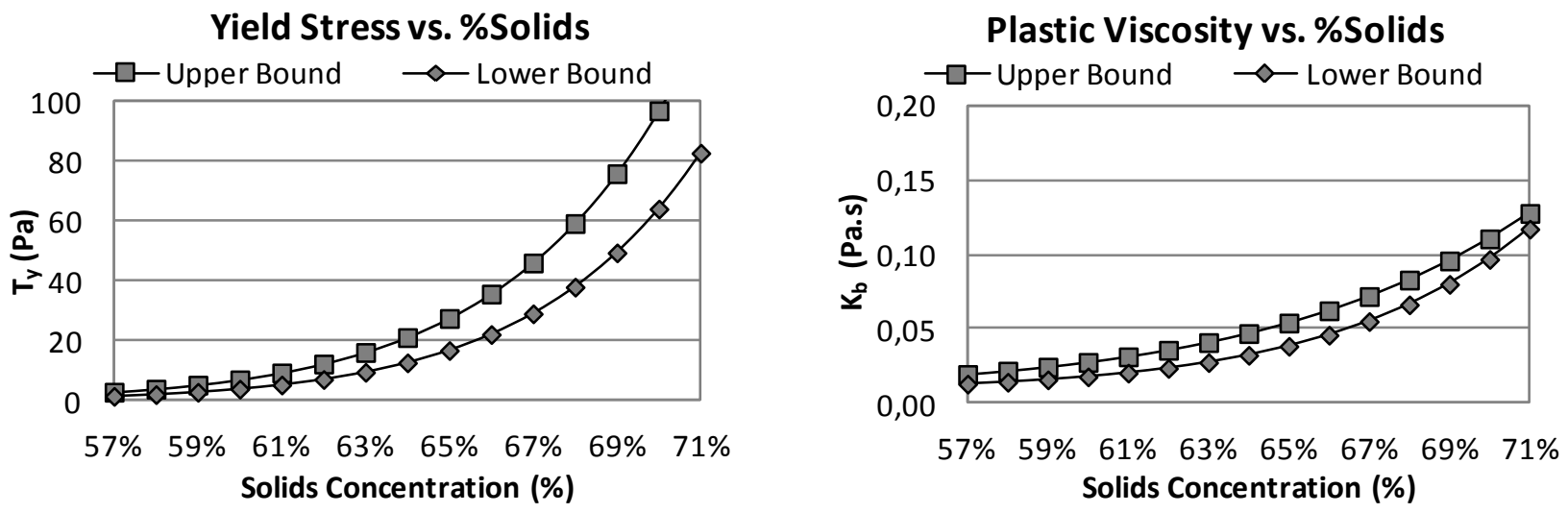

Figure 9 Pipe loop derived rheological parameters 
This paper is focused on the behaviour of high density thickened tailings once deposited within a storage facility for the Chuquicamata project in northern Chile. The fundamental objectives were to determine the deposition design appropriate to optimise density and therefore storage capacity while estimating full scale beach slopes for a range of solids concentrations from $57-68 \%$ solids. This was completed during a five month operation of a 70 tonne/day pilot plant commissioned in January 2011. The following sections present additional results derived from the data given in this paper.

\section{1 Water recovery}

The liberation of water within a tailings facility is an important consideration when determining the potential recovery for high density thickened tailings deposition. The results of the fixed flumes and laboratory testing indicate that the probability of recovering water from tailings deposited at $68 \%$ solids is likely to be very low to zero, whereas for $63-65 \%$ solids, some water recovery from the tailings facility could be expected. Table 6 presents an estimate of overall potential recovery volumes that could be expected based on the observations and data collected from the pilot plant and the Talabre deposit.

Table 6 Summary of water losses and potential recovery

\begin{tabular}{|c|c|c|c|c|c|c|c|}
\hline \multirow[b]{2}{*}{$\begin{array}{c}\text { Solids } \\
\text { Concentration } \\
\text { (\%) }\end{array}$} & \multicolumn{2}{|c|}{ Thickening } & \multicolumn{3}{|c|}{ Tailings Storage Area } & \multirow[b]{2}{*}{$\begin{array}{c}\text { Final } \\
\text { Recovery } \\
\text { over } 57 \% \\
\text { Solids }{ }^{3} \\
\text { (I/s) }\end{array}$} & \multirow[b]{2}{*}{$\begin{array}{c}\text { Average } \\
\text { Actual } \\
\text { Recovery- } \\
\text { Talabre } \\
\text { (I/s) }\end{array}$} \\
\hline & $\begin{array}{c}\text { Water in } \\
\text { Tailings } \\
(1 / s)\end{array}$ & $\begin{array}{c}\text { Water } \\
\text { Recovery } \\
\text { over 57\% } \\
\text { Solids } \\
\text { (I/s) }\end{array}$ & $\begin{array}{l}\text { Calculated } \\
\text { Water } \\
\text { Losses As- } \\
\text { Placed }^{1} \\
\text { (\%) }\end{array}$ & $\begin{array}{c}\text { Estimation of } \\
\text { Global Losses } \\
\text { (inc. Free } \\
\text { Water Evap.) } \\
\text { (I/s) }\end{array}$ & $\begin{array}{c}\text { Potential } \\
\text { Recovery } \\
(1 / s)\end{array}$ & & \\
\hline 57 & 1,965 & - & 77 & 1,534 & 431 & - & $560 *$ \\
\hline 63 & 1,529 & 435 & 83 & 1,285 & 244 & $249(680)$ & - \\
\hline 65 & 1,402 & 562 & 88 & 1,245 & 157 & $289(720)$ & - \\
\hline 68 & 1,225 & 739 & 97 & 1,191 & 34 & $342(773)$ & - \\
\hline
\end{tabular}

${ }^{1}$ Water recovery data as shown in Figure $7 ;{ }^{2}$ Includes pond evaporation for estimated pond sizes, reducing as concentration increases; ${ }^{3}$ Combined total in brackets; *Monthly data received from CODELCO 2000-2011.

The actual average monthly water reclaim within Talabre is $28 \%$ (average solids concentration of $56.6 \%$ ) from 2004 to 2011 data, whereas $23 \%$ was calculated during the operation of the fixed flumes and the laboratory. The difference is most likely due to higher layer thickness in Talabre, as tailings are currently deposited using the single point discharge technique, designed to maximise water recovery but reduce in situ density. Increasing the tailings concentration will reduce this variation in recovery (less water discharged).

In summary, water recovery from increased thickening will naturally recuperate higher volumes of water prior to deposition, with reduced final recovery from the tailings facility. This final recovery is an important consideration when analysing concentrations of high density thickened tailings discharge, as overall water recovery for increased solids concentrations may be only marginally higher. This may not be economically feasible when considering higher capital and operational costs that are generally associated with higher rates of thickening and pumping, particularly paste.

\section{2 Density and cycle times}

The results from the fixed flumes and laboratory tests show that the in situ densities (as-placed and final) will increase with solids concentration, as expected. However, as shown in Table 3 the in situ densities for 63-68\% are similar, with results for 65 and $68 \%$ solids almost identical. Therefore, from the exclusive point 
of view of in situ density gain, there is no advantage to increasing the tailings concentration beyond $65 \%$ solids and only a slight advantage to thickening higher than $63 \%$ solids. As identified in Table $4,65 \%$ solids will yield reduced drying times in comparison to tailings deposited at $68 \%$ solids, allowing faster rates of rise and reduced intensity for discharge management, which is a significant advantage, even when considering higher layer thicknesses.

\section{3 Beach slope predictions (stream power)}

The predicted beach profiles for $63 \%$ and $68 \%$ solids for the top final beach location and using the laboratory based parameters are indicated in Figures 10a and 10b.

(a)

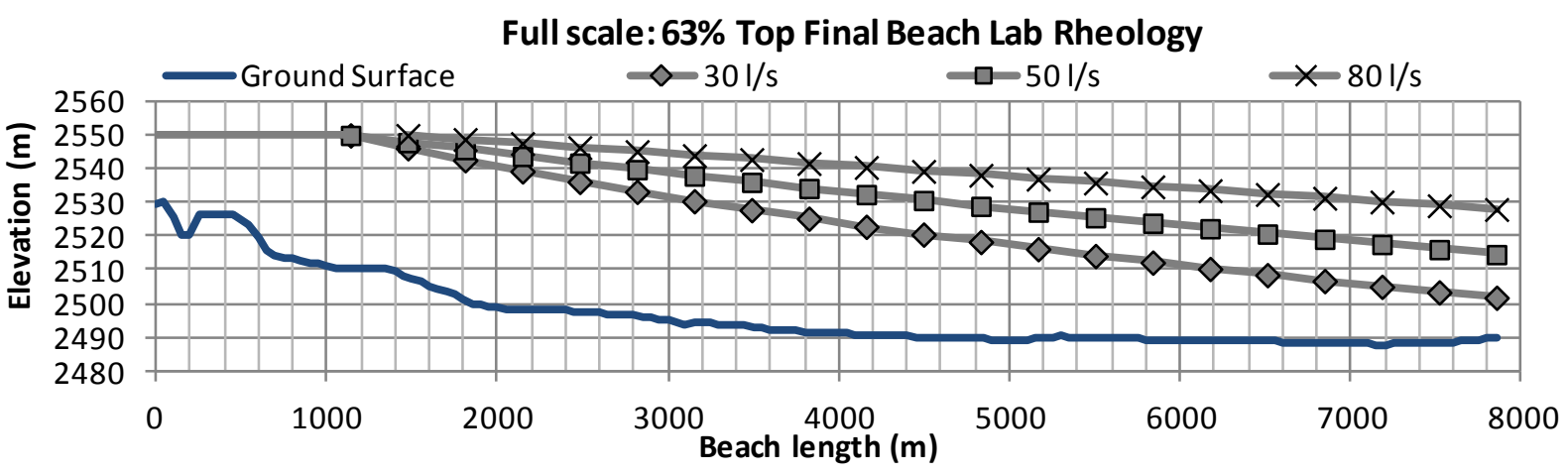

Full scale: 68\% Top Final Beach Lab Rheology

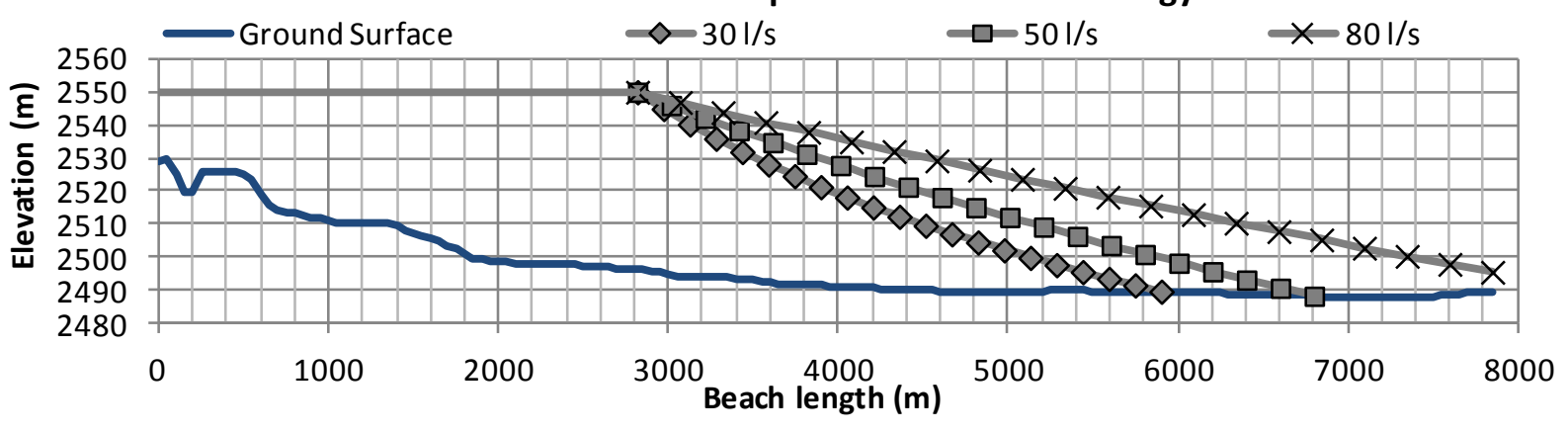

(b)

Figure 10 (a) $63 \%$ and (b) $68 \%$ solids, top final beach

The average beach slopes have been calculated in two ways, yielding identical numbers:

- By averaging the slopes calculated for each section of beach analysed in the course of the beach modelling.

- By taking the total elevation drop predicted by the modelling and dividing by the total predicted beach length.

The predicted slopes are summarised in Table 8, together with the maximum height differential between the predicted concave beach profile and a profile of single slope equal to the average slope. This provides an indication of the degree of concavity of the profile. It is evident from Table 8 that there is a significant increase in the beach slope as the flow rate per spigot is reduced.

Table 8 also presents the data for future ore variations, where beach slope predictions were made. There is a significant difference between the slopes for parameters derived from laboratory testing of existing tailings (pilot plant) and those derived from future tailings testing at higher concentrations.

It is also of interest to note that the predicted degree of concavity increases between 63 and $65 \%$ solids but decreases from $65-68 \%$ solids while the average beach slopes increase steadily over the range. This is in line with observations by pioneer researchers such as Eli Robinsky, that as the percentage solids increases 
the beach profile becomes steeper but more linear. In this case this transition is predicted to begin after $65 \%$ solids.

Table 8 Summary of predicted beach slopes (with future tailings predictions)

\begin{tabular}{|c|c|c|c|c|}
\hline Data Source & \% Solids & $\begin{array}{c}\text { Flow Rate } \\
(1 / s)\end{array}$ & $\begin{array}{l}\text { Average } \\
\text { Slope (\%) }\end{array}$ & Concavity* \\
\hline \multirow[t]{9}{*}{ Lab (existing tailings) } & \multirow[t]{3}{*}{$63 \%$} & 30 & $-0.72 \%$ & 5.44 \\
\hline & & 50 & $-0.53 \%$ & 1.65 \\
\hline & & 80 & $-0.34 \%$ & 0.29 \\
\hline & \multirow[t]{3}{*}{$65 \%$} & 30 & $-1.02 \%$ & 8.91 \\
\hline & & 50 & $-0.83 \%$ & 3.57 \\
\hline & & 80 & $-0.55 \%$ & 0.89 \\
\hline & \multirow[t]{3}{*}{$68 \%$} & 30 & $-1.95 \%$ & 7.71 \\
\hline & & 50 & $-1.55 \%$ & 4.08 \\
\hline & & 80 & $-1.08 \%$ & 1.83 \\
\hline \multirow{9}{*}{$\begin{array}{l}\text { Lab lower bound } \\
\text { (future tailings) }\end{array}$} & \multirow[t]{3}{*}{$63 \%$} & 30 & $-0.95 \%$ & 8.00 \\
\hline & & 50 & $-0.80 \%$ & 2.79 \\
\hline & & 80 & $-0.52 \%$ & 0.72 \\
\hline & \multirow[t]{3}{*}{$65 \%$} & 30 & $-1.61 \%$ & 8.08 \\
\hline & & 50 & $-1.32 \%$ & 4.16 \\
\hline & & 80 & $-1.00 \%$ & 2.02 \\
\hline & \multirow[t]{3}{*}{$68 \%$} & 30 & $-3.57 \%$ & 6.82 \\
\hline & & 50 & $-2.78 \%$ & 3.83 \\
\hline & & 80 & $-2.15 \%$ & 1.59 \\
\hline \multirow{9}{*}{$\begin{array}{l}\text { Lab upper bound } \\
\text { (future tailings) }\end{array}$} & \multirow[t]{3}{*}{$63 \%$} & 30 & $-1.64 \%$ & 7.58 \\
\hline & & 50 & $-1.32 \%$ & 4.05 \\
\hline & & 80 & $-0.95 \%$ & 1.10 \\
\hline & \multirow[t]{3}{*}{$65 \%$} & 30 & $-2.69 \%$ & 7.75 \\
\hline & & 50 & $-2.19 \%$ & 3.65 \\
\hline & & 80 & $-1.65 \%$ & 1.71 \\
\hline & \multirow[t]{3}{*}{$68 \%$} & 30 & $-5.44 \%$ & 6.62 \\
\hline & & 50 & $-4.40 \%$ & 3.38 \\
\hline & & 80 & $-3.41 \%$ & 1.38 \\
\hline
\end{tabular}

*Maximum height difference between average slope and concave beach profile.

\section{$7 \quad$ Closing comments}

Based on the observations of the fixed flumes (KP) and laboratory testing (KP), there are differences in the behaviour of the Chuquicamata tailings when deposited at concentrations above $57 \%$ solids. One important 
observation is that increasing the concentration increases the time taken to reach optimum dry density. Between $57-63 \%$, there is a point where this optimum in situ dry density is similar to values observed for 63-68\% solids, but is achieved in shorter time frames. Obtaining optimum dry densities is preferable due to the high throughput of Chuquicamata, and therefore the ability to extend the life of Talabre.

In addition to density behaviour, the water recovery and beach slope observations will assist with recommendations for future tailings discharge within Talabre. At this stage, increasing the concentration of tailings from the current thickener and revision of the existing transport system will be advantageous to optimise storage capacity before ore feeds from two other nearby CODELCO mines (Ministro Hales and Radomiro Tomic) commence processing operations. At this time, future water costs are likely to dictate the selected high density thickened tailings disposal concentration, due to the capital and operating costs associated with sea water make-up. A trade-off study will determine capital and operating costs prior to a conceptual design stage for Talabre. It is envisaged that the KP suite of laboratory scale testing will be carried out to verify the predicted changes in the deposition behaviour of these new tailings compared with the current tailings, and if necessary, further pilot plant testing.

Tailings properties are naturally different between mining projects, influencing the deposition behaviour and water recovery that could be achieved. It is therefore important to understand these properties in the early stages of project development by first considering laboratory scale trials to determine thickening and pumping limitations, as well as in situ densities and potential water liberation that could be expected within the tailings storage area. Knight Piésold's experience has shown that the suite of tests performed in the laboratory provide a good indication of potential full scale tailings deposition behaviour within a tailings storage facility (based on actual facilities now in operation). For the CODELCO pilot plant, the addition of testing in the fixed flumes (KP) has helped to verify observed deposition behaviour on a larger scale. The comparability between the two testing techniques questions the need to operate the fixed flumes in the future. This is especially true when considering the ease of duplicating required conditions in the laboratory when compared to larger scale field conditions where operational challenges exist to produce, transport and discharge high density thickened tailings, even on a pilot scale. However, it is likely that the fixed flumes will be modified in the future to run deposition testing in cells, in order to have more control over layer thickness for depths that cannot be achieved on a laboratory scale.

A comparison of rheological parameters derived from laboratory and fixed flume tests (McPhail) shows a relatively poor correlation. The degree of correlation is also influenced by the scale of the flume. Based on the results of this programme, it seems evident that the benefits of avoiding the issue of settling out of the slurry (as occurs in the laboratory testing) by adopting pilot scale flume tests, are offset by issues such as scale of the pilot test and stratification of the tailings as they flow down the flume. It needs, however, to be recognised that the issue of stratification occurs in the full scale operation and a method for adequately accounting for stratification will be essential for beach profile prediction going forward.

\section{Acknow ledgements}

The authors would like to thank CODELCO for the opportunity to be involved with the Chuquicamata Pilot Plant and for granting permission to prepare and present this paper.

\section{References}

Engels, J.M., Jamett, R.F., Albornoz, J.M., Arenas, M.R., Duarte, S.A. and Ramírez, R.R. (2011) Informe Operación Planta PilotoEnsayos Canaletas de Pendiente Fija, created for CODELCO-VP, by Knight Piésold S.A., Chile (confidential, cited with permission), N08CC01-P1-KPPCEIC-TRTAL-INFMD02-3370-163-B, pp. 371.

McPhail, G.I. (2011) Beach profile predictions for high density tailings at Chuquicamata Mine, created for Knight Piésold S.A. and CODELCO-VP, by SLR Consulting Australia (Pty) Ltd, Perth (confidential, cited with permission), 347-001 (1/11), pp. 58. 